\title{
Okul Yaşam Kalitesinin Bazı Değişkenlere Göre İncelenmesi
}

\author{
Erhan Tunç \\ Gaziantep Üniversitesi, Gaziantep, Türkiye erhantunc25@gmail.com \\ Mehmet Beşaltı \\ Birecik FSM Bostan İlköğretim Okulu, Urfa, Türkiye pdr_mehmet_besalti@hotmail.com
}

Received: 03.02.2014; Reviewed: 30.08.2014; Accepted: 20.10.2014

\section{ÖZET}

Okul yaşam kalitesinin bazı değişkenler açısından incelendiği bu çalışma, Şanlıurfa iline bağlı Birecik ilçesinde, 2012-2013 Öğretim yılında öğrenim görmekte olan 6. 7. ve 8. sınıf öğrencileri $(n=469)$ üzerinde yapılmıştır. Araşıırmanın verileri, araştırmacı tarafından geliştirilen kişisel bilgi formu ve Sarı (2007) tarafından geliştirilen Okul Yaşam Kalitesi Ölçeği (OYKÖ) ile toplanmıştır. Verilerin analizinde t-testi ile ANOVA kullanılmıştır. Araştırma sonucunda cinsiyet açısından; Okul Yaşam Kalitesi Ölçeği'nin "öğrenciler arasındaki iletişim" ve "öğretmen boyutu" alt ölçeklerinden elde edilen puanlar arasında; anne-babalarının birlikte veya ayrı yaşıyor olmalarına göre "öğretmen boyutu" alt ölçeğinden elde ettikleri puanlar arasında; algıladıkları sosyo-ekonomik düzeylerine göre "statü", "okul yönetimi", "okula yönelik duygular" ve "öğretmen boyutu" alt ölçeklerinden elde edilen puanlar ile ölçeğin toplamından alınan puanlar arasında; öğrencilerin kendilerini okul başarısı açısından algılama düzeylerine göre "statü", "okul yönetimi" ve "okula yönelik duygular" alt ölçeklerinden elde edilen puanlar arasında, anlamlı derecede farklılaşmalar olduğu görülmüştür.

Anahtar Kelimeler: Okul Yaşam Kalitesi (OYK), akademik başarı, okul yönetimi

\section{Study of School Life Quality Based on Certain Variables}

\begin{abstract}
This work researches the quality of school life related to different variables and was done in Birecik, Şanlıurfa on 2012-2013 school year with 6th 7th and 8th $(n=469)$ graders. Data from this research is collected through a personal information form developed by the researcher and the Quality of School Life Scale (Sari, 2007). ANOVA and t-test are used for analysing the data. Meaningful differentiation is observed in terms of gender for scores obtained from "relationships between the students" and "in terms of the teacher" subscales from the Quality of School Life Scale, scores they have obtained "in terms of the teacher" subscale depending on parents living together or separately, depending on their perceived socio-economical level "status", "school administration", "feelings toward the school", "in terms of the teacher" subscales and the scores obtained from the whole of the research, "status", "school administration", "feelings toward the school" subscales related to student's self-perceptions about school success.
\end{abstract}

Keywords: Quality of School Life, academic success, school administration 


\section{EXTENDED SUMMARY}

Educators and researchers research the subject quality of school life due to the fact that positive experiences during school life affecting the personality development of students and school life experiences being a preparation for students' future academical, personal and social lives. It should be reckoned that the first condition for the psychological environment which is called the class atmosphere is that it relies on mutual love and respect. In a healthy class atmosphere, there is no place for ignoring, insulting individuals and disvaluing their ideas. The attachment and love relationship between a student and his/her teacher affects the motivation and success of the student positively thus enabling them to develop a positive attitude towards school, education and learning. If the time periods of students that are spend in the classroom with their teachers and classmates are meaningful and fun experiences for them, they would also be developing positive attitudes towards the whole school. It has been shown in scientific research that the positive perceptions of the quality of classroom environment plays an important role in the students' perceptions of the quality of the school life. Kandemir and Özbay (2009) found a positive meaningful correlation between the classroom emphatic perception and students' self esteems and a negative one with bullying. This finding and similar findings are important on pointing out the importance of the teacher-student relationship. The quality of the teacher-student relationship affects the academical success and student behaviour. Hallinan (2008) point outs two basic components in teacher-student interaction which affect the students' feelings about school: Social-emotional support from the teacher and the character of teacher's expectations about students' academical performances. It would not be very hard for a teacher who can approach emphatically regarding these two components and satisfy students' expectations to help develop them positive feelings towards the school.

This work researches the quality of school life related to different variables and was done in Birecik, Şanliurfa on 2012-2013 school year with 6th 7th and 8th $(n=469)$ graders. Data from this research is collected through a personal information form developed by the researcher and Quality of School Life Scale (Sari, 2007). ANOVA and t-test are used for analysing the data.

The result of this research points out considering the genders of the students, the Quality of School Life Scale "in terms of the teacher" a meaningful differentiation of higher subscale scores are observed for boys and higher "relationships between the students" subscale scores are observed for girls; considering "status", "school administration" and "feelings toward the school", there was no meaningful differentiation.

No meaningful differentiation of scores for the Quality of School Life Scale as a whole or its subscales was observed related to the school grade students were studying at.

There was a meaningful differentiation of scores for the Quality of School Life Scale for "in terms of the teacher" subscale in favour of students with separated parents, though there were no meaningful differentiation of scores for "school administration", "feelings towards the school" or "relationships between the students" subscales.

Related to the perceived socio-economical levels, there was a meaningful differentiation of scores for the Quality of School Life Scale for "status", "school administration", "feelings towards the school" and "in terms of the teacher" subscales' scores compared with the score of the whole scale were higher for students with "middle" and "high" socio-economical perception. There was no meaningful differentiation for "relationships between the students" subscale.

Related to the perceived school success levels, there was a meaningful differentiation of scores for the Quality of School Life Scale for "status", "school administration" and the "feelings towards the school" subscales' scores which were higher for students who perceive themselves with "average" and "low" success levels, on "relationships between the students" subscale scores were higher for students who perceive themselves with "low" success levels, for the whole scale scores were higher for students who perceive themselves with "average" and "low" success levels and for the subscale "in terms of the teacher", no meaningful differentiation of scores was observed.

As a conclusion, it can be observed that different educators take different variables into account for researches on quality of school life. For example, according to Karatzias, Power and Swanson (2001), indicators for the quality of school life is school program, attendance, teaching methods, etching styles, learning, personal needs, evaluation, value systems for the individuals and the school, support, career, relationships, objective environmental factors, and subjective environmental factors. According 
to Johnson and Stevens (2001), variables for the quality of school life are support offered to the student, close relationships, innovations, participation to decisions and availability of resource. According to Fish and Dane (2000), variables are adaptation (emotional attachments, supportiveness and limitations), flexibility, (leadership, discipline, exchanging ideas, roles and rules) and communication (listening abilities, speaking abilities, self-assessment, clearness, continuity/observation, respect and consideration). Dorman (1999) who has researched the quality of school life on higher education had used the variables, academic freedom, importance given to graduate study, research and being scientific, giving authority, close relationships, agreement about the mission and work pressure. (Ref: Sari, 2010). On this research, the quality of school life has been studied according to gender, class, parents being together or separate, perceived success rate and perceived socio-economical level. 


\section{GİRIŞ}

İnsanoğlunun varoluşuyla birlikte eğitimin önemi vuku bulmuştur. Bununla birlikte her geçen gün eğitimin önemi zirve yapmıştır. Gelişen teknolojiyle birlikte insanlar eğitimin ne kadar önemli olduğunu fark etmişlerdir. Bütün dünya ülkelerinin en önemli yatırımı eğitim olduğunu varsayarsak; bir ülkenin kalkınması gelişmesi modernleşmesi ve dünya ülkeleri içinde kendini prestijli bir konumda bulabilmesi için eğitim seviyelerinin yüksek olması gerekir. Güneydoğu bölgesi için eğitim gelişmenin modernleşmenin garantisi olacaktır. $\mathrm{Bu}$ garantiyi elde etmenin yollarından bir tanesi de öğrencilerimizin okullarımıza yönelik beslediği duygulardır. Booker (2004) ise öğrencilerin arkadaşları ve öğretmenleriyle olumlu ve destekleyici etkileşimler yaşadıklarında, okul topluluğuna daha üst düzeyde bağlandıklarını belirtmektedir. Öğrencilerin okulu sevmelerinin en önemli nedeni olarak arkadaşlarını göstermeleri, ergenlik dönemindeki çocuklar için doğal bir durumdur.

İnsanoğlu doyumsuz olması nedeniyle hiçbir zaman eğitimde doyum noktasına ulaşılmamıştır bundan dolayı her geçen gün eğitim ihtiyaçları artmaktadır. Eğitimin temel sermayesi de bizlerin yetiştirdiği öğrencilerdir. Çünkü öğrencilerimiz ülkemizin yaşam standartlarını arttıracak, rahat, modern gelişmiş bir ülkede yaşama fırsatını sağlayacaklardır. Eğitimin temel yapı taşlarından bir tanesi de okullarımızdır, okullarımızı güzelleştirmek eğitim öğretim bakımından fiziki koşullarını en üst düzeye çıkarmak için devlet tarafından uzun vadeli politikalar izlenir. Eğitimin meyvesi güzel ancak uzun zamanlıdır verimi yılları alır. Onun için eğitimdeki değişimler ve yenilikler hemen etkisini göstermez zamanla meyvesini verir.

\section{Okul Yaşam Kalitesi}

Okullara daha bütüncül bir perspektifle yaklaşan anlayışlar, "iyi bir okul"un tek göstergesi olarak akademik performansın alınmasına karşı çıkmakta ve öğrencilerin yaratıcılık yeteneğinin geliştirilmesi ile fiziksel, duygusal ve sosyal iyi olma hallerinin desteklenmesine de vurgu yapmaktadırlar (Weston, 1998). McNeely, Nonnemaker ve Blum (2002), ergenlerin, okullarındaki diğerleri tarafindan önemsendiklerini hissettiklerinde ve kendilerini okullarının bir parçası olarak gördüklerinde, küçük yaşta madde kullanmaya, şiddet içerikli durumlara karışmaya ya da cinselliğe daha az eğilimli olduklarını belirtmektedir. Karatzias ve diğerleri (2001), okul yaşam kalitesinin tanımlanması zor bir kavram olduğunu, bununla birlikte okul yaşam kalitesinin, okulla ilgili faktörler ve öğrencilerin okul yaşamı ve kültürüne katılmaları sonucunda edindikleri eğitsel yaşantılar tarafından belirlenen genel bir iyi olma haline işaret ettiğini belirtmektedir. Okul yaşam kalitesi, öğrencilerin akademik başarası ve eğitimin diğer çıktıları üzerindeki önemli etkileri nedeniyle, eğitimciler tarafından özel bir ilgi görmüş ve çocukların okuldaki iyi olma halleriyle ilgili birçok araştırma yapılmıştır (Mok ve Flynn, 2002; Sinclair ve Fraser, 2002, Bilgiç ve Sarı 2010). Çocukların okulda sahip oldukları yaşam kalitesinin, akademik başarıları üzerinde de önemli etkileri bulunduğu bilimsel araştırmalarla ortaya konulmuştur. Örneğin Bourke ve Smith (1989) yaptıkları araştırmalarda, öğrencilerin okul yaşam kalitesinin akademik başarılarında etkili olduğunu ve daha iyi bir okul yaşamına sahip öğrencilerin zorunlu öğrenimi tamamladıktan sonra da eğitimlerine devam etmeyi daha fazla istediklerini ortaya koymuşlardır. Mok ve Flynn'ın (1997) elde ettiği bulgular ise, okulun yaşam kalitesinin, öğren-cilerin akademik başarısındaki varyansın \%20'sini açıkladığı yönündedir. Öte yandan, araştırmalar, okul tatminsizliğinin ve öğrencinin kendini okula ait hissetmeyişinin davranışsal problemlerle ve düşük başarıyla pozitif yönde ilişkili olduğunu ve okula yabancılaşma gibi sonuçlar doğurduğunu göstermektedir (Goodenow, 1992a, 1992b; Goodenow ve Grady, 1993). Örneğin Jaavall (2007), öğrencilerin okul yaşam kalitesi algılarını etkileyen en önemli faktörün, öğretmenleriyle olan ilişkileri olduğunu, öğretmenlerin adanmışlık ve öğrencileriyle ilgilenme düzeylerinin öğrenciler tarafından en önemli etken olarak kabul edildiğini belirlemiştir. Okula yönelik olumsuz düşüncelere sahip olmak ise, öğrencinin okuldaki günlük yaşamın tatmin edici olmamasına yol açıp öğrenmenin önünde bir engel oluşturabilir (Johnson ve Johnson, 1993). Okul yasam kalitesi, kısaca okuldaki bireylerin her yönden mutlu olabildikleri bir ortamı ifade etmektedir. Okul yasam kalitesi, genel iyi olma halinin göstergelerinden biri olarak kabul edilmekte ve çocukların okul yaşamıyla bütünleşmelerinden kaynaklanan bir iyi olma hali olarak ele alınmaktadır. Çocukların uzun yıllarını okulda geçirdikleri göz önüne alındığında, okul yasam kalitesinin taşıdığı önem açıkça görülebilmektedir. Genelde eğitim, özelde de eğitim yönetimi ile ilgili olarak yapılan çalışmalarda göze çarpan bir özellik, sadece yönetici ve öğretmenlerin görüşlerine başvurulmuştur. Fakat okulda bulunan unsurlar içerisinde okuldan en çok etkilenen grup öğrencilerdir. 
Çünkü öğrenciler yaşamlarının büyük bir kısmını okul ortamında geçirmektedirler. Okul varlığının ilk sebebi öğretmenler ve yöneticiler değil öğrenciler ve toplumdur (Y1lmaz, 2005, s.2). Bu araştırma okullarda eğitimin kalitesinin değerlendirilmesi konusunda öğrencilerin görüşlerine başvurduğu için önemlidir. Bu araştırmada kullanılan Okul Yaşam Kalitesi Ölçeği’nde öğrencilerin okul yaşam kalitesi algıs1, beş alt boyut olarak ölçülmüştür. Bunlar; statü, okul yönetimi, okula yönelik duygular, öğrenciler arasındaki iletişim, öğretmen Boyutu'dur.

Okula Yönelik Duygular; Okul yasam kalitesinin bu boyutu, öğrencilerin okul hakkındaki bütün olumlu ve olumsuz duygu, düşünce ve tutumlarının genel bir sonucu niteliğindedir. Çocukların okula kars1 olan tutumları, hisleri, kısaca okula karsı sahip olduklar1 bütün duygular bu boyut altında incelenmektedir (Mok ve Flynn, 2002: 281). Okula Yönelik Duygular adı altında birleştirilen olumlu duygu ile olumsuz duygu boyutları, okul yasam kalitesinin ana değişkenleri olarak da ele alınabilir. Çünkü diğer boyutlar bu iki genel boyutu yakından etkilemektedirler. Örneğin, eğer çocuğun okulda öğretmenleriyle, diğer öğrencilerle ve yöneticilerle iletişimi iyi değilse, kendini okulda değerli hissetmiyorsa ya da geleceğine yönelik olarak okulun kendisine akademik ve sosyal anlamda herhangi bir şans yaratabileceğini düşünmüyorsa, okuldaki sosyal etkinlikler ilgisini çekmiyorsa, bu öğrencinin okul yasam kalitesine yönelik algısı da olumsuz bir yapı gösterecektir (Sarı, 2007: 76).

Statü; Bu boyut, çocuğun okulda kendini ne kadar değerli ve önemli hissettiği ile ilgilidir (Mok ve Flynn, 2002). İnsanların diğer insanlarla güvenli bir şekilde iletişim kurmaya, kendini değerli hissetmeye, sevmeye ve saygı duyulmaya ihtiyacı vardır (Stipek,1996; Akt: Arastaman, 2006: 50). İnsanlar ait olduğu gruba olumlu yönde bir katkı sağladığını düşündügünde basarı için de motive olurlar (Voke, 2002: 3). Dolayısıyla çocukların da zamanlarının önemli bir bölümünü geçirdikleri okulda belli ve özel bir yere sahip olduklarını, öğretmenleri ve arkadaşları için değerli olduklarını hissetmek istemeleri doğaldır. Öğrencilerin kendilerine saygı duyulduğunu hissettikleri, eşitliği ve kuralların açıklığını gördükleri, planlamada ve kuralların uygulanmasında söz sahibi oldukları okullarda öğrenciler okullarına daha bağlıdır ve daha mutludurlar (Hernandez ve Seem, 2004 Akt: Çamur, 2006: 67). Bilgiç ve Sarı (2010)'ya göre bundan dolayı öğrencilerin kendilerini nerede gördükleri akademik başarı için önem arz eder.

Öğretmen-Öğrenci iletişimi; Çocuk akran grubunda, yetişkin yaşamında öğretilmesinden kaçınan yasak konuların burada rahatça tartışılması ve konuşulması olanağını bulur. Akran guruplarında birey, aileden bağımsız hareket etme, liderlik, otoriteyi tanıma, farklı sosyal sınıflara ait davranış kalıplarını öğrenme, işbirliği yapma gibi yaşantılar kazanır (Tezcan, 1997). Öğretmenler özellikle sosyal değerlerin ve kültürün öğrencilere aktarılması ve öğrencilerin kişisel ve sosyal gelişimlerinin arttırılması konusunda önemli bir role sahiptirler. Problemleri konusunda öğrenciye yardım etmeye gönüllü, planlanmış övgü ve ödül dağıtan, öğrenciden beklentiler ile beraber öğrencinin güvenini arttıran öğretmenler öğrenci performansını ve okul yasam kalitesini arttırmaktadırlar (Leonard, 2002: 29). Okul yasam kalitesi, öğrenci çıktıları ve okul devamlılığı, öğrencileri ile sempatik, yaklaşılır ve güvenilir iletişime daha çok vakit ayıran öğretmenler tarafından arttırılır. Okul iklimini etkileyen öğretmen faktörleri arasında öğrencileri serbest bırakmanın seviyesi, engelleme, tatmin ve iliksilerin yakınlığı sayılabilir (Leonard, 2002: 69). İlkokul çocuklarının öğretmenleriyle iliksileri okul başarılarını, okul tatminini ve okul toplumuna ait olma hislerini etkilemektedir. Yani bir çocuğun okul tatmini öğretmenini sevme derecesine bağlı olabilir. İlkokul öğrencileri üzerine yapılan bir araştırmaya göre (Verkuyten ve Thijs, 2002: 206) öğretmenlerin sınıf içindeki olumsuz olaylara tepkileri akran zorbalığının sıklığını azaltmakta ve öğrencilerin öğretmenlerine karsı tutumlarını geliştirmektedir.

Öğrenci-Öğrenci iletişimi; Çocuğun ya da gencin toplumsallaşması sürecinde önemli bir işlevi olan akran etkileşimi, birey için önemli bir bilgi kaynă̆ıdır. Akran gruplarında birey, aileden bağımsız hareket etme, liderlik, otoriteyi tanıma, farklı sosyal sınıflara ait davranış kalıplarını öğrenme, cinsiyet rollerini öğrenme, işbirliği yapma gibi yaşantılar kazanır (Bursalıŏlu, 2005). Akranları tarafından kabul gören çocuklar sınıf ve okul ortamlarından daha çok zevk almaya eğilimli bulunmuşlardır. Bunun da ötesinde, akran statüsünün okul algısı ve öz değerlendirme üzerinde arkadaşlıktan daha etkili olduğu bulunmuştur. Örneğin akranları tarafından kabul edilmeyen çocukların yasam kalitesi ile ilgili büyük bir tatminsizlik ifade ettikleri bulunmuştur ( Green v.d., 1980, Akt: Verkuyten ve Thijs, 2002: 203

Okul Yönetimi; Okul denilen örgütün eğitim sistemi içindeki yeri ve önemi, okulun eğitim yönetimini oluşturan, sistemin en stratejik parçası bulunuşundan ve eğitimi değerlendirebilme araçlarının basında gelmesinden doğmaktadır. Bu nedenlerden dolayı okul yönetimi ve liderinin sistemin başarısı 
üzerindeki etkisi büyük olmaktadır (Çamur, 2006: 31). İyi okulu kötü okuldan ayıran etken, örgütün yapısından çok, havasına ve içinde bulunduğu ortama iliksindir. Bunu geliştirecek olan da okulun yöneticisidir. Okul yöneticisinin hem kişisel hem de mesleki olarak sahip olduğu özellikler, okulun hangi nitelikte bir örgüt olacağını belirleyecektir (Sarı, 2007: 87). Ders dısı sosyal etkinlikler düzenlemek okul yönetimi tarafından kontrol edilebilir bir faktördür. Okul yönetiminin öğrencilerin umduğu, beklediği ve istediği ders dişı sosyal etkinlikleri düzenlemek ve sağlamak, öğrencilerin derse ve okula karsı ilgi düzeyini ve katılımını arttıracaktır (Arastaman, 2006: 39).

Öğrencilerin sınıf içerisinde öğretmenleri ve diğer öğrencilerle geçirdiği zaman dilimleri onlar için anlamlı ve eğlenceli yaşantılardan oluşuyorsa, okulun geneline karşı da olumlu tutumlar geliştireceklerdir. $\mathrm{Bu}$ nedenlerden dolayı ihtiyaç duyulan bu çalışmanın temel amacı, ilköğretim altıncı, yedinci ve sekizinci sınıf öğrencilerinin okul yaşam kalitesi algılarını bazı değişkenlere göre incelemektir.

$\mathrm{Bu}$ amaç doğrultusunda aşağıdaki sorulara yanıt aranmıştır:

1. İlköğretim ikinci kademedeki öğrencilerin okul yaşam kalitesine yönelik algıları nasıldır?

2. Illköğretim ikinci kademedeki ögrencilerin okul yaşam kalitesinin cinsiyete, sinıf düzeyine, SED, anne babanın birlikte olma durumuna ve algiladıklarl okul başarllarına göre anlamlı bir fark var midir?

\section{YÖNTEM}

$\mathrm{Bu}$ araştırmada betimsel tarama modelinde ilişkisel tarama yöntemi kullanılmıştır. Araştırmaya konu olan olay, birey ya da nesne, kendi koşulları içinde var olduğu gibi tanımlanmaya çalışılır. Onları herhangi bir şekilde değiştirme, etkileme çabası gösterilmez. Genel tarama modelleri, çok sayıda elemandan oluşan bir evrende, evren hakkında genel bir yargıya varmak amacı ile, evrenin tümü ya da ondan alınacak bir grup, örnek ya da örneklem üzerinde yapılan tarama düzenlemeleridir (Karasar 2006).

\section{Çalışma Grubu}

$\mathrm{Bu}$ çalışmaya 2012-2013 eğitim öğretim yılında, Şanlıurfa ili Birecik merkezde seçkisiz olarak belirlenen üç ortaöğretim okulundan 6. , 7. ve 8. Sınıf öğrencilerinden toplam 469 öğrenci katılmıştır. Öğrencilerin $219(\% 46,7)$ erkek ve $250(\% 53,3)$ kız öğrencilerden oluşmaktadır. Altıncı sınıf 185 $(\% 39,4)$, yedinci sınıf $139(\% 29,6)$ ve sekizinci sınıftan $144(30,7)$ katılımcı oluşmaktadır.

\section{Veri Toplama Araçları}

Sarı (2007) tarafından geliştirilen Okul Yaşam Kalitesi Ölçeği (OYKÖ) ile araştırmacı tarafından oluşturulan kişisel bilgi formu kullanılmıştır. Ölçek beş alt boyuttan (Statü, Okul Yönetimi, Okula yönelik Duygular, Öğrenciler Arasındaki İletişim, Öğretmen Boyutu) oluşmuş olup 35 madde içermektedir. OYKÖ beşli bir derecelendirmeyle yanıtlanmaktadır. Ölçekte 15 olumsuz (bu ifadeler ters çevrilerek puanlanmaktadır), 20 de olumlu madde bulunmaktadır. Bu bağlamda ölçekten alınabilecek en düşük puan 35 , en yüksek puan $175^{\prime}$ dir. Cronbach alfa iç tutarlılık katsayıları sırasıyla $.85, .78, .76, .65, .53, .61$ ve ölçeğin tamamı için de .86'dır (Sarı, 2007).

\section{Verilerin Analizi}

Araştırmada toplanan veriler, bilgisayarda SPSS 16.00 istatistik Programı yardımı ile hesaplanmıştır. Öğrencilerin okul yasam kalitesine ilişkin görüşlerinin belirlenmesinde aritmetik ortalama ve standart sapma değerleri bulunmuş, bu değerlerin öğrencilerin anne- babaların birlikte olup olmadıklarıyla ve cinsiyetine göre farklılık gösterip göstermediğine ilişkisiz t-testi ile sınıf düzeyin, sosyoekonomik durumlarına ve okul başarılarına göre farklılık gösterip göstermediğine tek yönlü varyans analizi (One-way ANOVA) ile bakılmıştır.

\section{Sayıltılar ve Sinırlılıklar}

Araştırmamızın örneklemi evreni temsil ettiği, araştırmaya katılanların soruları objektif bir şekilde cevapladıkları, kullanılan ölçeklerin geçerli ve güvenilir olduğu varsayılmıştır. 
Bu araştırma 2012-2013 yılı Şanlıurfa iline bağlı Birecik ilçesinde öğrenim gören 6. ,7. Ve8. Sınıf öğrencileriyle sınırlıdır. Sarı (2007) tarafından geliştirilen okul yaşam kalitesi ölçeği ve araştırmacı tarafından hazırlanan kişisel bilgi formuyla sınırlıdır.

\section{BULGULAR}

Araştırmanın ana problemi ve buna bağlı olarak oluşturulan alt problemlerine cevap bulmak amaciyla elde edilen veriler üzerinde istatistiksel işlemler yapılmış ve aşağıdaki bulgular elde edilmiştir.

\section{Araştırmanın Birinci Problemine İlişkin Olarak Elde Edilen Bulgular ve Yorum:}

"Öğrencilerin cinsiyetlerine göre Okul Yaşam Kalitesi ölçeğinden aldıkları puanlar anlamlı düzeyde farklılaşmakta mıdır?" sorusuna cevap bulmak için t testi analizinden yararlanılmış ve elde edilen bulular Tablo 1.'de sunulmuştur.

Tablo 1. Öğrencilerin Cinsiyetlerine Göre Okul Yaşam Kalitesi Ölçeğinden Aldıkları Puanlar Arasındaki Farklılaşma Düzeyine İlişkin t Testi Sonuçları

\begin{tabular}{|c|c|c|c|c|c|}
\hline $\begin{array}{l}\text { Okul Yaşam Kalitesi } \\
\text { Ölçeğini Alt Boyutları }\end{array}$ & Cinsiyet & $\begin{array}{l}\text { Aritmetik } \\
\text { Ortalama }\end{array}$ & S.s. & $\mathrm{t}$ & $\mathrm{p}$ \\
\hline \multirow[t]{2}{*}{ Statü } & Kız & 10,49 & 3,09 & \multirow{2}{*}{1,85} & \multirow{2}{*}{, 06} \\
\hline & Erkek & 11,02 & 3,00 & & \\
\hline \multirow{2}{*}{ Okul Yönetimi } & $\mathrm{K} 1 \mathrm{z}$ & 18,39 & 5,07 & \multirow{2}{*}{, 31} & \multirow{2}{*}{,75 } \\
\hline & Erkek & 18,55 & 5,54 & & \\
\hline \multirow{2}{*}{ Okula yönelik Duygular } & $\mathrm{K} 1 \mathrm{z}$ & 27,50 & 6,50 & \multirow{2}{*}{1,48} & \multirow{2}{*}{, 13} \\
\hline & Erkek & 28,46 & 7,38 & & \\
\hline \multirow{2}{*}{ Öğrenciler Arasındaki İletişim } & $\mathrm{K} 1 \mathrm{z}$ & 25,77 & 7,86 & \multirow{2}{*}{1,95} & \multirow{2}{*}{, $05 *$} \\
\hline & Erkek & 24,36 & 7,76 & & \\
\hline \multirow{2}{*}{ Öğretmen Boyutu } & $\mathrm{K} 1 \mathrm{z}$ & 30,36 & 6,76 & \multirow{2}{*}{2,66} & \multirow{2}{*}{, $00 *$} \\
\hline & Erkek & 31,93 & 6,06 & & \\
\hline \multirow{2}{*}{ Toplam Puan } & Kiz & 114,33 & 16,07 & \multirow{2}{*}{1,15} & \multirow{2}{*}{, 24} \\
\hline & Erkek & 112,53 & 17,45 & & \\
\hline
\end{tabular}

Tablo 1. incelendiğinde; öğrencilerin cinsiyetlerine göre Okul Yaşam Kalitesi Ölçeği’nin "öğretmen boyutu" alt ölçeğinden elde edilen puanlar arasında erkekler lehine, "öğrenciler arasındaki iletişim" alt ölçeğinden elde edilen puanlar açısından da kızlar lehine anlamlı farklılaşmalar olduğu; "statü”, "okul yönetimi", "okula yönelik duygular" alt ölçeklerinden elde edilen puanlar arasında ve ölçeğin toplamından elde edilen puanlar arasında anlamlı farklılaşmalar olmadığı görülmüş̧ür.

Durmaz (2008), tarafindan yapılan bir araştırmada; "öğretmen- öğrenci iletişimi”, "okul yönetimi” ve "sosyal etkinlikler" alt boyutlarının tümünde kız öğrenciler lehine anlamlı derecede farklılaştığı, diğer alt boyutlardan ve ölçeğin toplamından elde edilen puanların ortalamaları arasındaki farklarında istatistiksel olarak anlamlı olmadığı bulunmamıştır.

Malin ve Linakyla (2001), Marks (1998), Bourke ve Smith (1989) ve Karatzias v.d.nin (2002) yaptıkları çalışmalarda kız öğrencilerin erkek öğrencilerle karşılaştırıldığında okullarındaki yasam kalitesini daha olumlu algıladıkları ortaya konmuştur. Kız öğrenciler erkek öğrencilere nispeten okul yaşamlarından daha çok memnundurlar. Ayrıca bu çalışmalarda kız öğrenciler özellikle öğretmenöğrenci iletişimi boyutunda ve ölçeğin tamamından elde edilen puanlar açısından da erkek öğrencilerden daha yüksek puanlar almışlardır.

Mok ve Flynn'in (2002) çalışmasında da kız ve erkek öğrencilerin okul yasam kalitesi ile ilgili algıları arasında kız öğrenciler lehine anlamlı farklılıklar bulunmuştur (Akt: Durmaz, 2008).

\section{Araştırmanın İkinci Problemine İlişskin Olarak Elde Edilen Bulgular ve Yorum:}

"Öğrencilerin öğrenim görmekte oldukları sınıf düzeylerine göre Okul Yaşam Kalitesi ölçeğinden aldıkları puanlar anlamlı düzeyde farklılaşmakta mıdır?" sorusuna cevap bulmak için tek yönlü varyans (ANOVA) analizinden yararlanılmış ve elde edilen bulular Tablo 2.'de sunulmuştur. 
Tablo 2. Öğrencilerin Öğrenim Gördükleri Sınıf Düzeylerine Göre Okul Yaşam Kalitesi Ölçeğinden Aldıkları Puanlar Arasındaki Farklılaşma Düzeyine İlişkin ANOVA Sonuçları

\begin{tabular}{|c|c|c|c|c|c|}
\hline $\begin{array}{l}\text { Okul Yaşam Kalitesi } \\
\text { Ölçeğinin Alt Boyutları }\end{array}$ & $\begin{array}{l}\text { Sinıf } \\
\text { Düzeyi }\end{array}$ & $\begin{array}{l}\text { Aritmetik } \\
\text { Ortalama }\end{array}$ & S.s. & $\mathrm{F}$ & $\mathrm{p}$ \\
\hline & 6.sinif & 10,38 & 3,20 & & \\
\hline \multirow[t]{3}{*}{ Statü } & 7.sinıf & 11,12 & 2,99 & 1,90 &, 12 \\
\hline & 8.sinıf & 10,91 & 2,87 & & \\
\hline & 6.sinif & 18,58 & 5,00 & & \\
\hline \multirow[t]{3}{*}{ Okul Yönetimi } & 7.sinif & 18,15 & 4,94 &, 33 &, 79 \\
\hline & 8.sinif & 18,68 & 6,06 & & \\
\hline & 6.sinif & 28,00 & 6,39 & & \\
\hline \multirow[t]{3}{*}{ Okula yönelik Duygular } & 7.sinif & 28,30 & 6,77 &, 15 & ,92 \\
\hline & 8.sinif & 27,74 & 7,94 & & \\
\hline & 6.sinif & 25,25 & 7,98 & & \\
\hline \multirow[t]{3}{*}{ Öğrenciler Arasındaki İletişim } & 7.sinif & 25,33 & 7,52 & ,69 &, 55 \\
\hline & 8.sinif & 25,48 & 7,95 & & \\
\hline & 6.sinif & 31,15 & 6,53 & & \\
\hline \multirow[t]{3}{*}{ Öğretmen Boyutu } & 7.sinif & 30,88 & 7,08 & 28 &, 83 \\
\hline & 8.sinıf & 31,56 & 5,65 & & \\
\hline & 6.sinif & 113,58 & 15,26 & & \\
\hline \multirow{2}{*}{ Toplam Puan } & 7.sinif & 113,80 & 16,98 &, 12 & ,94 \\
\hline & 8.sinif & 113,39 & 18,64 & & \\
\hline
\end{tabular}

Tablo 2. incelendiğinde; öğrencilerin öğrenim görmekte oldukları sınıf düzeylerine göre Okul Yaşam Kalitesi Ölçeği'nin alt ölçeklerinden ve ölçeğin toplamından aldıkları puanlar arasında anlamlı derecede farklılaşmalar görülmemektedir.

Bilgiç ve Sarı (2010) yaptıkları bir araştırmada; Okul Yaşam Kalitesi Ölçeği puanlarına ait ortalamalar arasında, 6.sınıf öğrencilerinin ortalamaları ile 7. ve 8.sınıf öğrencilerinin ortalamaları arasında, 6 . sınıf öğrencileri lehine anlamlı farklar olduğu belirlenmişken, 7. ve 8.sınıf öğrencilerinin ortalamaları arasındaki farkların anlamlı olmadığı görülmüş̧ür.

Ölçeğin "okula yönelik duygular" alt boyutunda 9. sınıf öğrencileri ile 11.sınıf öğrencileri arasında 9.sınıf öğrencileri lehine görülen anlamlı farka ve ölçeğin toplam puanında 9.sınıf öğrencilerinin en yüksek ortalamayı elde etmelerine gelince aslında bu bulgular da alan yazındaki bulgularla paraleldir. Çünkü sınıf düzeyi arttıkça okul tatmini azalmaktadır. Bunun sebebi de öğretmenler tarafından öğrencilere gösterilen kişisel ilginin sınıf düzeyi arttıkça düşmesi ve yine sınıf düzeyi arttıkça öğrencilerin okulda alınan kararlara katılımının azalması, gelecek endişelerinin artması ve meslek seçimi döneminde olmaları gösterilmektedir (Okun v.d., 1990; Akt: Karatzias v.d., 2002: 35).

\section{Araştırmanın Üçüncü Problemine İlişkin Olarak Elde Edilen Bulgular ve Yorum:}

"Öğrencilerin anne-babalarının birlikte olup olmadığına göre Okul Yaşam Kalitesi ölçeğinden aldıkları puanlar anlamlı düzeyde farklılaşmakta mıdır?" sorusuna cevap bulmak için $t$ testi analizinden yararlanılmış ve elde edilen bulular Tablo 3.'de sunulmuştur.

Tablo 3. Öğrencilerin Anne-Babalarının Birlikte Olup Olmadığına Göre Okul Yaşam Kalitesi Ölçeğinden Aldıkları Puanlar Arasındaki Farklılaşma Düzeyine İlişkin t Testi Sonuçları

\begin{tabular}{|c|c|c|c|c|c|}
\hline $\begin{array}{l}\text { Okul Yaşam Kalitesi } \\
\text { Ölçeğinin Alt Boyutları }\end{array}$ & $\begin{array}{l}\text { Anne babanın birlikte } \\
\text { Yaşayıp yaşamadığı }\end{array}$ & $\begin{array}{l}\text { Aritmetik } \\
\text { Ortalama }\end{array}$ & S.s. & $\mathrm{t}$ & $\mathrm{p}$ \\
\hline \multirow{2}{*}{ Statü } & Birlikte & 10,75 & 3,03 & \multirow{2}{*}{, 56} & \multirow{2}{*}{, 57} \\
\hline & Ayr1 & 11,05 & 3,37 & & \\
\hline \multirow{2}{*}{ Okul Yönetimi } & Birlikte & 18,43 & 5,34 & \multirow{2}{*}{,69 } & \multirow{2}{*}{, 48} \\
\hline & Ayr1 & 19,08 & 5,18 & & \\
\hline \multirow{2}{*}{ Okula yönelik Duygular } & Birlikte & 27,93 & 7,02 & \multirow{2}{*}{,98 } & \multirow{2}{*}{, 32} \\
\hline & Ayr1 & 29,14 & 6,67 & & \\
\hline \multirow{2}{*}{ Öğrenciler Arasındaki İletişim } & Birlikte & 25,16 & 7,74 & \multirow{2}{*}{1,44} & \multirow{2}{*}{, 14} \\
\hline & Ayrı & 23,17 & 8,89 & & \\
\hline \multirow{2}{*}{ Öğretmen Boyutu } & Birlikte & 31,01 & 6,43 & \multirow{2}{*}{,94 } & \multirow{2}{*}{, $02 *$} \\
\hline & Ayr1 & 33,62 & 6,10 & & \\
\hline \multirow[t]{2}{*}{ Toplam Puan } & Birlikte & 113,29 & 16,85 & \multirow{2}{*}{2,38} & \multirow{2}{*}{, 34} \\
\hline & Ayr1 & 115,86 & 16,87 & & \\
\hline
\end{tabular}


Tablo 3. incelendiğinde; öğrencilerin anne-babalarının birlikte veya ayrı yaşıyor olmalarına göre Okul Yaşam Kalitesi Ölçeği'nin "öğretmen boyutu" alt ölçeğinden elde ettikleri puanlar arasında annebabası ayrı yaşayanlar lehine anlamlı derece farklılaşmalar olduğu, ölçeğin "okul yönetimi”, "okula yönelik duygular", ve "öğrenciler arasındaki iletişim" alt ölçeklerinden ve ölçeğin toplamından elde edilen puanlar arasında da anlamlı farklılaşmalar olmadığı görülmektedir.

\section{Araştırmanın Dördüncü Problemine İlişkin Olarak Elde Edilen Bulgular ve Yorum:}

"Öğrencilerin algıladıkları sosyo-ekonomik düzeylerine göre Okul Yaşam Kalitesi ölçeğinden aldıkları puanlar anlamlı düzeyde farklılaşmakta mıdır?" sorusuna cevap bulmak için tek yönlü varyans (ANOVA) analizinden yararlanılmış ve elde edilen bulular Tablo 4.'de sunulmuştur.

Tablo 4. Öğrencilerin Algıladıkları Sosyo-Ekonomik Düzeylerine Göre Okul Yaşam Kalitesi Ölçeğinden Aldıkları Puanlar Arasındaki Farklılaşma Düzeyine İlişkin ANOVA Sonuçları

\begin{tabular}{|c|c|c|c|c|c|}
\hline $\begin{array}{l}\text { Okul Yaşam Kalitesi } \\
\text { Ölçeğinin Alt Boyutları }\end{array}$ & $\begin{array}{l}\text { Algilanan } \\
\text { SED }\end{array}$ & $\begin{array}{l}\text { Aritmetik } \\
\text { Ortalama }\end{array}$ & S.s. & $\mathrm{F}$ & $\mathrm{p}$ \\
\hline & Zayıf & 9,84 & 3,25 & & \\
\hline \multirow[t]{3}{*}{ Statü } & Orta & 11,05 & 2,81 & 6,44 &, $00 *$ \\
\hline & İyi & 11,03 & 3,26 & & \\
\hline & Zayıf & 10,66 & 5,55 & & \\
\hline \multirow[t]{3}{*}{ Okul Yönetimi } & Orta & 18,16 & 5,27 & 6,61 &, $00 *$ \\
\hline & İyi & 20,07 & 4,95 & & \\
\hline & Zayıf & 25,77 & 6,81 & & \\
\hline \multirow[t]{3}{*}{ Okula yönelik Duygular } & Orta & 28,56 & 6,89 & 7,13 &, $00 *$ \\
\hline & İyi & 28,82 & 6,96 & & \\
\hline & Zayıf & 25,58 & 8,50 & & \\
\hline \multirow[t]{3}{*}{ Öğrenciler Arasındaki İletişim } & Orta & 24,87 & 7,64 & 0,34 &, 71 \\
\hline & İyi & 24,86 & 7,66 & & \\
\hline & Zayıf & 29,81 & 7,59 & & \\
\hline \multirow[t]{3}{*}{ Öğretmen Boyutu } & Orta & 31,74 & 6,23 & 3,42 &, $03 *$ \\
\hline & İyi & 31,29 & 6,64 & & \\
\hline & Zayıf & 108,67 & 16,26 & & \\
\hline \multirow[t]{2}{*}{ Toplam Puan } & Orta & 114,39 & 16,34 & 6,08 &, $00 *$ \\
\hline & İyi & 116,08 & 17,79 & & \\
\hline
\end{tabular}

Tablo 4. incelendiğinde; öğrencilerin algıladıkları sosyo-ekonomik düzeylerine göre Okul Yaşam Kalitesi Ölçeğinin "statü", "okul yönetimi”, "okula yönelik duygular" ve "öğretmen boyutu" alt ölçeğinden elde edilen puanlar ile ölçeğin toplamından aldıkları puanlar arasında sosyo-ekonomik düzeylerini orta ve yüksek düzeyde algılayanların lehine anlamlı derece farklılaşmalar olduğu, ölçeğin "öğrenciler arasındaki iletişim" alt ölçeğinden aldıkları puanlar arasında da anlamlı farklılaşmalar olmadığ görülmektedir.

Sarı (2012) yaptığı bir araştırmada; LİSEYKÖ puanlarına ait ortalamaların 2.90-3.06; ESATÖ puanlarına ait ortalamaların 2.90-3.17; ABÖ puanlarına ait ortalamaların ise 3.67-3.92 arasında olduğu görülmektedir. Öğrencilerin LİSEYKÖ ve ESATÖ puanları arasındaki farklar okulun sosyoekonomik düzeyine göre anlamlı bir fark görülmemiştir. $(p<.05)$.

Araştırmanın Beşinci Problemine İliş̧kin Olarak Elde Edilen Bulgular ve Yorum:

"Öğrencilerin algıladıkları okul başarısı düzeylerine göre Okul Yaşam Kalitesi ölçeğinden aldıkları puanlar anlamlı düzeyde farklılaşmakta mıdır?" sorusuna cevap bulmak için tek yönlü varyans (ANOVA) analizinden yararlanılmış ve elde edilen bulular Tablo 5.'de sunulmuştur. 
Tablo 5. Öğrencilerin Algıladıkları Okul Başarı Düzeylerine Göre Okul Yaşam Kalitesi Ölçeğinden Aldıkları Puanlar Arasındaki Farklılaşma Düzeyine İlişkin ANOVA Sonuçları

\begin{tabular}{|c|c|c|c|c|c|}
\hline $\begin{array}{l}\text { Okul Yaşam Kalitesi } \\
\text { Ölçeğinin Alt Boyutları }\end{array}$ & $\begin{array}{l}\text { Algılanan okul } \\
\text { Başarısı düzeyi }\end{array}$ & $\begin{array}{l}\text { Aritmetik } \\
\text { Ortalama }\end{array}$ & S.s. & $\mathrm{F}$ & $\mathrm{p}$ \\
\hline & Zayıf & 9,84 & 3,25 & & \\
\hline \multirow{3}{*}{ Statü } & Orta & 11,05 & 2,81 & 11,45 &, $00 *$ \\
\hline & İyi & 11,03 & 3,26 & & \\
\hline & Zayıf & 17,66 & 5,55 & & \\
\hline \multirow[t]{3}{*}{ Okul Yönetimi } & Orta & 18,16 & 5,27 & 9,98 &, $00 *$ \\
\hline & İyi & 20,07 & 4,95 & & \\
\hline & Zayıf & 25,77 & 6,81 & & \\
\hline \multirow[t]{3}{*}{ Okula yönelik Duygular } & Orta & 28,56 & 6,89 & 10,74 &, $00 *$ \\
\hline & İyi & 28,82 & 6,96 & & \\
\hline & Zayıf & 25,58 & 8,50 & & \\
\hline \multirow[t]{3}{*}{ Öğrenciler Arasındaki İletişim } & Orta & 24,87 & 7,64 & 11,80 &, $00 *$ \\
\hline & İyi & 24,86 & 7,66 & & \\
\hline & Zayıf & 29,81 & 6,59 & & \\
\hline \multirow[t]{3}{*}{ Öğretmen Boyutu } & Orta & 31,74 & 6,28 & ,49 & ,61 \\
\hline & İyi & 31,29 & 6,64 & & \\
\hline & Zayıf & 114,12 & 12,41 & & \\
\hline \multirow[t]{2}{*}{ Toplam Puan } & Orta & 109,94 & 15,35 & 13,43 &, $00 *$ \\
\hline & İyi & 116,76 & 17,27 & & \\
\hline
\end{tabular}

Tablo 5 incelendiğinde; öğrencilerin okul başarısı açısından kendilerini algılama düzeylerine Okul Yaşam Kalitesi Ölçeğinin "statü”, "okul yönetimi” ve "okula yönelik duygular" alt ölçeğinden elde edilen puanlar arasında kendilerini orta ve zayıf başarı düzeyinde algılayanlar lehine; "öğrenciler arasındaki iletişim” alt ölçeğinden aldıkları puanlara göre kendilerini zayıf düzeyde algılayanların lehine; ölçeğin toplamından aldıkları puanlar açısından da kendilerini zayıf ve iyi başarı düzeyinde algılayanlar lehine anlamlı farklılaşmalar olduğu; ancak ölçeğin " "öğretmen boyutu" alt ölçeğinden aldıkları puanlar arasında anlamlı derecede farklılaşmalar olmadığı görülmektedir.

\section{TARTIŞMA ve SONUÇLAR}

Bu çalışma, Şanlıurfa iline bağlı Birecik ilçesinde 2012-2013 öğretim yılında öğrenim görmekte olan 6. 7. ve 8. Sınıf öğrencilerinden oluşan 469 kişilik bir grup üzerinde yapılmış ve okul yaşam kalitesi; cinsiyet, sınıf düzeyi, anne-babanın birlikte olup olmadığı, algıladıkları sosyo-ekonomik düzey ve algıladıkları okul başarı düzeyleri gibi değişkenler açısından incelenmiştir. Araştırma bulguları incelendiğinde;

Öğrencilerin cinsiyetlerine göre Okul Yaşam Kalitesi Ölçeği'nin "öğretmen boyutu” alt ölçeğinden elde edilen puanlar arasında erkekler lehine, "öğrenciler arasındaki iletişim" alt ölçeğinden elde edilen puanlar açısından da kızlar lehine anlamlı farklılaşmalar olduğu; "statü", "okul yönetimi", "okula yönelik duygular" alt ölçeklerinden elde edilen puanlar arasında ve ölçeğin toplamından elde edilen puanlar arasında anlamlı farklılaşmalar olmadığı görülmüştür.

Durmaz (2008), tarafindan yapılan bir araştırmada; "öğretmen- öğrenci iletişimi”, “okul yönetimi” ve "sosyal etkinlikler" alt boyutlarının tümünde kız öğrenciler lehine anlamlı derecede farklılaştığı, diğer alt boyutlardan ve ölçeğin toplamından elde edilen puanların ortalamaları arasındaki farklarında istatistiksel olarak anlamlı olmadığı bulunmamıştır.

Malin ve Linakyla (2001), Marks (1998), Bourke ve Smith (1989) ve Karatzias v.d.nin (2002) yaptıkları çalışmalarda kız öğrencilerin erkek öğrencilerle karşılaştırıldığında okullarındaki yasam kalitesini daha olumlu algıladıkları ortaya konmuştur. Kız öğrenciler erkek öğrencilere nispeten okul yaşamlarından daha çok memnundurlar. Ayrıca bu çalışmalarda kız öğrenciler özellikle öğretmenöğrenci iletişimi boyutunda ve ölçeğin tamamından elde edilen puanlar açısından da erkek öğrencilerden daha yüksek puanlar almışlardır.

Mok ve Flynn'in (2002) çalışmasında da kız ve erkek öğrencilerin okul yasam kalitesi ile ilgili algıları arasında kız öğrenciler lehine anlamlı farklılıklar bulunmuştur (Akt: Durmaz, 2008). 
Öğrencilerin öğrenim görmekte oldukları sınıf düzeylerine göre Okul Yaşam Kalitesi Ölçeği’nin alt ölçeklerinden ve ölçeğin toplamından aldıkları puanlar arasında anlamlı derecede farklılaşmalar görülmemektedir.

Bilgiç ve Sarı (2010) yaptıkları bir araştırmada; Okul Yaşam Kalitesi Ölçeği puanlarına ait ortalamalar arasında, 6.sınıf öğrencilerinin ortalamaları ile 7. ve 8.sınıf öğrencilerinin ortalamaları arasında, 6 . sınıf öğrencileri lehine anlamlı farklar olduğu belirlenmişken, 7. ve 8.sınıf öğrencilerinin ortalamaları arasındaki farkların anlamlı olmadığı görülmüştür.

Ölçeğin “okula yönelik duygular” alt boyutunda 9. sınıf öğrencileri ile 11.sınıf öğrencileri arasında 9.sınıf öğrencileri lehine görülen anlamlı farka ve ölçeğin toplam puanında 9.sınıf öğrencilerinin en yüksek ortalamayı elde etmelerine gelince aslında bu bulgular da alan yazındaki bulgularla paraleldir. Çünkü sınıf düzeyi arttıkça okul tatmini azalmaktadır. Bunun sebebi de öğretmenler tarafından öğrencilere gösterilen kişisel ilginin sınıf düzeyi arttıkça düşmesi ve yine sınıf düzeyi arttıkça öğrencilerin okulda alınan kararlara katılımının azalması, gelecek endişelerinin artması ve meslek seçimi döneminde olmaları gösterilmektedir (Okun v.d., 1990; Akt: Karatzias v.d., 2002: 35).

Öğrencilerin anne-babalarının birlikte veya ayrı yaşıyor olmalarına göre Okul Yaşam Kalitesi Ölçeği'nin "öğretmen boyutu" alt ölçeğinden elde ettikleri puanlar arasında anne-babası ayrı yaşayanlar lehine anlamlı derece farklılaşmalar olduğu, ölçeğin "okul yönetimi", "okula yönelik duygular", ve "öğrenciler arasındaki iletişim" alt ölçeklerinden ve ölçeğin toplamından elde edilen puanlar arasında da anlamlı farklılaşmalar olmadığı görülmektedir.

Öğrencilerin algıladıkları sosyo-ekonomik düzeylerine göre Okul Yaşam Kalitesi Ölçeğinin "statü", "okul yönetimi”, "okula yönelik duygular" ve "öğretmen boyutu" alt ölçeğinden elde edilen puanlar ile ölçeğin toplamından aldıkları puanlar arasında sosyo-ekonomik düzeylerini orta ve yüksek düzeyde algılayanların lehine anlamlı derece farklılaşmalar olduğu, ölçeğin "öğrenciler arasındaki iletişim”" alt ölçeğinden aldıkları puanlar arasında da anlamlı farklılaşmalar olmadığı görülmektedir.

Sarı (2012) yaptı̆̆ bir araştırmada; LİSEYKÖ puanlarına ait ortalamaların 2.90-3.06; ESATÖ puanlarına ait ortalamaların 2.90-3.17; ABÖ puanlarına ait ortalamaların ise 3.67-3.92 arasında olduğu görülmektedir. Öğrencilerin LİSEYKÖ ve ESATÖ puanları arasındaki farklar okulun sosyoekonomik düzeyine göre anlamlı bir fark görülmemiştir. ( $p<.05)$.

Öğrencilerin okul başarısı açısından kendilerini algılama düzeylerine Okul Yaşam Kalitesi Ölçeğinin "statü”, "okul yönetimi" ve "okula yönelik duygular" alt ölçeğinden elde edilen puanlar arasında kendilerini orta ve zayıf başarı düzeyinde algılayanlar lehine; "öğrenciler arasındaki iletişim" alt ölçeğinden aldıkları puanlara göre kendilerini zayıf düzeyde algılayanların lehine; ölçeğin toplamından aldıkları puanlar açısından da kendilerini zayıf ve iyi başarı düzeyinde algılayanlar lehine anlamlı farklılaşmalar olduğu; ancak ölçeğin "'öğretmen boyutu" alt ölçeğinden aldıkları puanlar arasında anlamlı derecede farklılaşmalar olmadığı görülmektedir.

\section{KAYNAKLAR}

Arastaman, G. (2006). Ankara İli Lise Birinci Sınıf Öğrencilerinin Okula Bağlllık Durumlarına İliskin Öğrenci, Öğretmen ve Yöneticilerin Görüşleri. Yayımlanmamış Yüksek Lisans Tezi, Ankara Üniversitesi Eğitim Bilimleri Enstitüsü Eğitim Bilimleri Anabilim Dalı, Ankara.

Bilgiç, S. ve Sarı, M. (2010). İlköğretim Öğrencilerinin Okul Yaşam Kalitesi ve Empatik Sınıf Atmosferi Algıları. Ĕgitim Bilimleri ve Uygulama, 9(17), 1-19

Booker, K. C. (2004). Exploring School Belonging and Academic Achievement in African American Adolescents. Curriculum and Teaching Dialogue, 6(2), 131-143.

Bourke, S. \& Smith, M. (1989). Quality of School Life and İntentions for Further Education: The Case of Rural High School. A paper presented at the annual conference of the Australian Association for Research in Education at Adelaide, November-December 1989, South Australia.

Bursalığlu, Z. (1979). Okul Yönetiminde Yeni Yapı ve Davranış. Ankara Üniversitesi Eğitim Fakültesi Yayınları, No:78

Bursalığlu, Z. (2005): Okul Yönetiminde Yeni Yapı ve Davranış, Ankara: Pegem A Yayıncılık, 13. Baskı.

Çamur,E, (2006). Liselerde Öğrenme Iklimine Iliskin Yönetici, Öğretmen, Veli ve Öğrenci Görüşleri. Yayımlanmamış Yüksek Lisans Tezi, Ege Üniversitesi Sosyal Bilimler Enstitüsü Eğitim Yönetimi Teftişi Planlaması ve Ekonomisi Anabilim Dalı, İzmir.

Durmaz, A. (2008). Liselerde Okul Yaşam Kalitesi Kırklareli İli Örneği. Yayınlanmış yüksek lisans tezi. Trakya Üniversitesi, Sosyal Bilimler Enstitüsü, Edirne. 
Goodenow, C. (1992a). Strengthening The Links Between Educational Psychology and The Study of Social Contexts. Educational Psychologist, 27, 177-196.

Goodenow, C. (1992b, April). School Motivation, Engagement, and Sense of Belonging Among Urban Adolescent Students. Paper presented at the Annual Meeting of the American Educational Research Association. San Francisco, CA.

Goodenow, C., \& Grady, K. E. (1993). The Relationship of School Belonging and Friends' Values to Academic Motivation Among Urban Adolescent Students. The Journal of Experimental Education, 62(1), 60-71

Hallinan, M. T. (2008). Teacher Influences on Students' Attachment to School. Sociology of Education, 81(3), 271-283.

Jaavall, I. M. H. (2007). Quality of School Life for Working Students: A Study Conducted Among Working Students of 8th Grade in A Primary School in Addis Ababa, Ethiopia. Master Thesis, University of Oslo, Norway.

Johnson, W. L. \& Johnson, A. M. (1993). Validity of the Quality of School Life Scale: A Primary and SecondOrder Factor Analysis. Educational and Psychological Measurement, 53, 145-153.

Kandemir, M. ve Özbay, Y. (2009). Sınıf İçinde Algılanan Empatik Atmosfer ile Benlik Saygısı Arasındaki Etkileşimin Zorbalıkla İlişkisi. Elementary Education Online, 8(2), 322-333.

Karatzias, A., Power, K., \& Swanson, V. (2001). Quality of School Life. Development and Preliminary Standardization of an Instrument Based on Performance Indicators in Scottish Secondary Schools. School Effectiveness and School Improvement, 12(3), 265-284.

Karatzias, A., Power, K.G., Flemming, J., Lennan, F. \& Swanson, V. (2002). The Role of Demographics, Personality Variables and School Stress on Predicting School Satisfaction/ Dissatisfaction. Review of The Literature and Research Findings, Educational Psychology, 22 (1), 33-50.

Leonard,C.A.R. (2002). Quality Of School Life And Attendance In Primary Schools Yayımlanmamıs Doktora Tezi, Newcastle Üniversitesi, Newcastle.

Malin,A. \& Linakkyla, P.(2001). Multilevel Modelling in Repeated Measures of The Quality of Finnish School Life. Scandinavian Journal of Educational Research, 45 (2), 145-165.

McNeely, A. C., Nonnemaker, J., M., \& Blum, R. W. (2002). Promoting school connectedness: Evidence from the national longitudinal study of adolescent health. Journal of School Health, 72(4), 138-146.

Mok, M. \& Flynn, M. (2002). Determinants of Students' Quality of School Life: A Path Model. Learning Environments Research, 5(3), 175-300.

Mok, M. M. C. \& Flynn, M. (1997). Does School Size Affect Quality of School Life? Issues in Educational Research, 7(1), 69-86.

Sarı, M. (2007). Demokratik Değerlerin Kazanımı Sürecinde Örtük Program: Düşük Ve Yüksek Okul Yasam Kalitesine Sahip İki İlköğretim Okulunda Nitel Bir Çalışma. Yayımlanmamış Doktora Tezi, Çukurova Üniversitesi Sosyal Bilimler Enstitüsü Eğitim Bilimleri Anabilim Dalı, Adana.

Sarı, M. (2012). Empatik Sınıf Atmosferi ve Arkadaşlara Bağlılık Düzeyinin Lise Öğrencilerinin Okul Yaşam Kalitesine Etkisi. Kuram ve Uygulamada Eğitim Yönetimi [Educational Administration: Theory and Practice], 18(1), 95-119.

Sinclair, B. \& Fraser, B. J. (2002). Changing Classroom Environments in Urban Middle Schools. Learning Environments Research, 5, 301-328.

Tezcan, M. (1997). Ĕgitim Sosyolojisi. Ankara Üniversitesi, Eğitim Bilimleri Fakültesi Yayınları No:50 Ankara.

Verkuyten, M. ve Thijs, J. (2002). School Satisfaction Of Elementary School Children: The Role Of Performance, Peer Relations, Ethnicity And Gender. Social Indicators Research, 59 (2), 203.

Voke, H. (2002): Motivating Students to Learn, (http://www.k12.wa.us/SecondaryEducation/relevance/pubdocs/MotivatingStudentstoLearn.doc. Erisim tarihi: 07.03. 2008).

Weston, R. (1998). Quality of school life in government, catholic and other private secondary schools: Views of students and their parents. Australian Institute of Family Studies Family Matters, 50, 56-61.

Yılmaz, K. (2005). İlköğretim Okulu Öğrencilerinin Okul Yaşamının Niteliğine İlişkin Görüsleri. Pamukkale Üniversitesi Eğitim Fakültesi Dergisi, 1 (17), 1-13. 